Binghamton University

The Open Repository @ Binghamton (The ORB)

The Society for Ancient Greek Philosophy Newsletter

1955

\title{
Gorgias and the Socratic Principle Nemo Sua Sponte Peccat
}

\author{
Guido Calogero \\ University of Rome La Sapienza
}

Follow this and additional works at: https://orb.binghamton.edu/sagp

Part of the Ancient History, Greek and Roman through Late Antiquity Commons, Ancient Philosophy Commons, and the History of Philosophy Commons

\section{Recommended Citation}

Calogero, Guido, "Gorgias and the Socratic Principle Nemo Sua Sponte Peccat" (1955). The Society for Ancient Greek Philosophy Newsletter. 7.

https://orb.binghamton.edu/sagp/7

This Article is brought to you for free and open access by The Open Repository @ Binghamton (The ORB). It has been accepted for inclusion in The Society for Ancient Greek Philosophy Newsletter by an authorized administrator of The Open Repository @ Binghamton (The ORB). For more information, please contact ORB@binghamton.edu. 


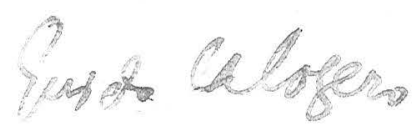

Gorgis" Holene and Palamedes and the Socratio principle nemo sua sponte peceat.

More than one centugy ago the great German philologist Welker tried to confirm the tradition, that amongst the so= phists the real mator of Socratos bad been Prodicus Welker called bim bis "forerunder"(1). In our century this valuation wa orce cxaggerated to the extent of maintaining that the principle of Prodicus - that is, tho case for the oxact distinction and usage of the mening of synongm- bad beon the starting point for every sound dovelopment in logic, we= reas the methodical pattern presupposed by socrates in his dIscussions was, on the contrary, 2 Pringip der absoluten Vieldeutigkeit, a pinciple of absolute equivocation and am biguity, and therefore the starting point for erery kind of trouble in that rield(2)。

Of course, the connection of socrates with Prodicus was justified by the foet that both, in their conversations, $2 p$ peared frequently to be disstisfied by cortain ansers or expressions of their interlocutors, and therefore discussed the meanings of certain terms used by them. But the differen= ce botween the two aproaches was very sharp, as it appears Irom every pasage of the socratio dialogues of Plato in whicb Prodicus is introduced to explain the demands of bis synonymics in the midst of the dobate(3). He mants everybody to use, for exmple, the verb Ḿ the verb tipexiveikin some otbors, following what be thinks

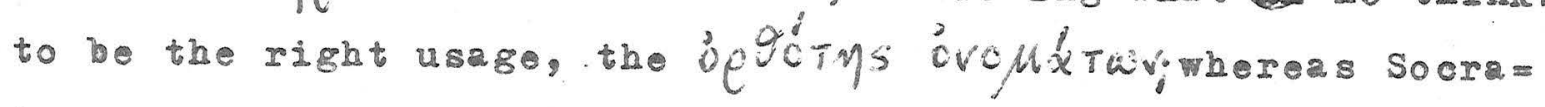
tes does not care what kind of words one may uso, but is only interested in what one really oxpresses by these words, that is, the mening which be gives to thom. Both search for means 


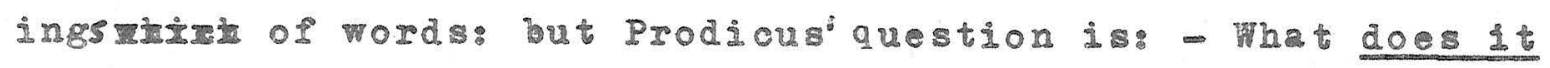
men?, - nd Socrates question is: - What do you moan? - Pro= dicus says: - xijpeix means this, Hexcitys means that: so

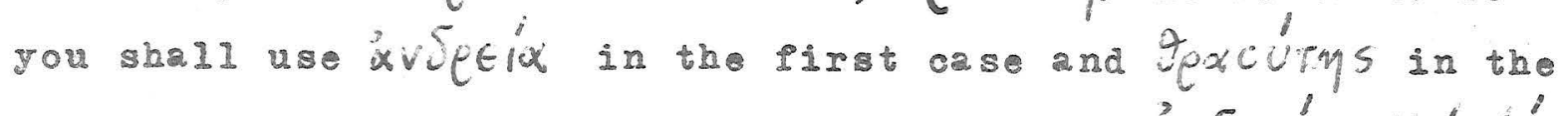
second. Socrates asks: - What do you mean by drvetia (Ti hez

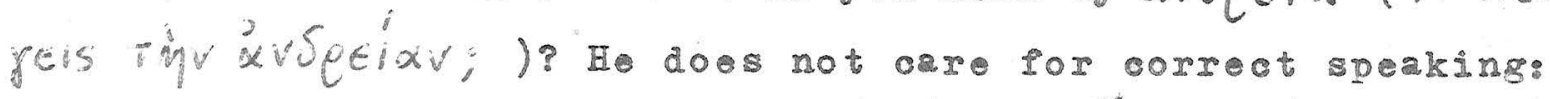
be bimsols likes to speak eikn Tois ent TuXovir ovopaci (as he says in PIators spology, 17C). He is intorested in the real thing, in what is meant, In the human behaviour which bas to be chosen and in the buman valuation wim chas to bo givono so Prodicus is the forerunor of 2.1 those poole who try to de tormine the proper meanings of the words of a language and to

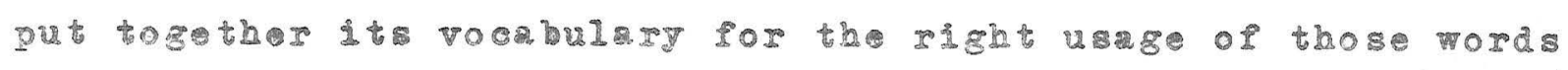
so long a the pasag of time dos not change their manings, and 180 of those who writo treatises on 10 glo or semantica in the boliel that the right knowledge of the menings of a languge is the bost method for reasoning weIl. Socrates, In= stead. Is the perennial master of the rol way of roasoning well. stressing not so mucb 10 gic but dialogic, that is, ne ver protending to know the true mening of mat bas beon said by others bofore $6 \xi \in$ T.x $\zeta \in$ V them and nevor pretending to be immediately understood by others without Shoval hófor to them, in that incesant dialogue wich is the moral life of meno

Now, this socratic idor. of the dalogue is strictly con nected with the basic principle of his ethics, nemo sua spon=

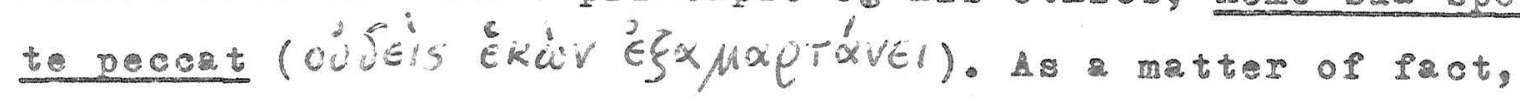
only a person who understands that nobody acts in a cartain way witbout preferring it to any other possible way of acton. of which be is aware, can be interested in linding out what are the reasons for such 2 preferenco, wibout being cartain in advance that they are wrong(4). And that principle is clear 
$1 y$ presupposad in the Helena and in the Palamedes Gorgiaso This sophist, therefore, might oventually be considored as the for= - runner of Socrates with more reason than Prodicus, albough none of bis interpreters, as for as I know, seems to bave sum spected such a connoction(5).

Lot us see the in argument of the Encomin on Helen. After baving briorly recalled ber origin ard bouty, Gorgias bogins the treatment of the ral subject of his speech, which is not so mucb an eulogy as an apology, as it was remarked by Isocra= tos(6). Gorgias wants, as bo says, wo subject ber story to critical examination, and so rescre ber from ignorant calumy (T) His point is that she actod as she did becase sho was irresi= stibly compolied to do so. As long as such a compulsion is sup= posed to have been determined by iúM or by AVX YkM or by the God or the violenco of a man, there is no question: her inno= cence is obvious. But now Corgias maintains that she was irro sistibly compelled, and therefore deprived of any it $^{\prime} \alpha$, even if the compulsion was only enacted through the $\overline{1} \in \mathcal{J}_{\dot{\omega}}$, the persuasion: - and this despite the pact that pix and riel were for his contemporaries the precise technical terms used to express the opposition between coercive and non-coercive behaviour, as the distingusbilly characters of tyranny and de mocracy, of slavery and frodom.

This is evidently the main contention which Gorgias bas to prove, and so be devotes to it the seven central paragraphs of his speech (8-14: seren precede and seven follow), beginning with expression of his conviction that, although bis task may apper difficult, it will be oasy for bim to fulfill it: É SE

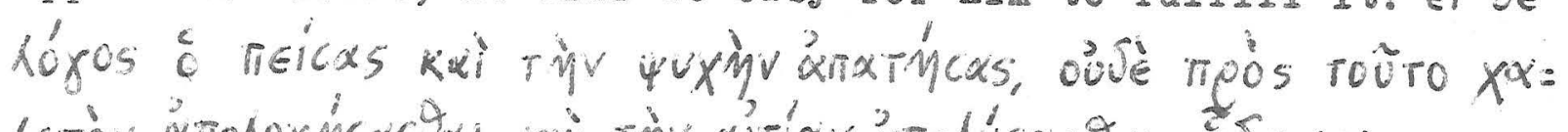

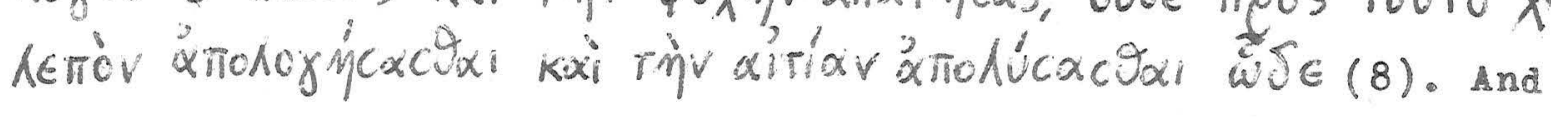
bere immediatoly follows the famous passage on the power of 
logos: Which has

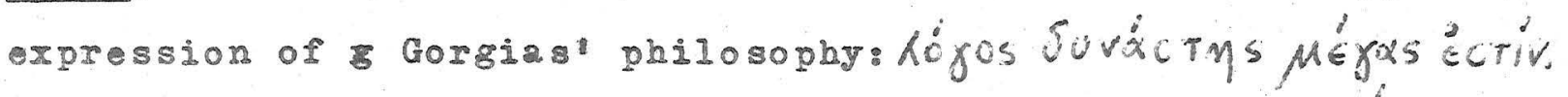
This power is not only the emotional force of poetry, $A$ ofos EXW METPOr, or the magic wizardry of incantations: it is also the power which we would call the persuasive force of reason:

(13) That Persuasion, when added to speach, can a so make ay impression it wishes to the soul, can be shown, rixsty, from the arguments of the meteorologists, wo by remoring one opinion and implanting another, cause what incredible and invisible to apper belore the eyes of the minds secondiy, Irom legal contests, in which a speech can sway and persuade a crowd, by the skill of its compositions, not by tho truth of bis state ments; thirdly, from the philosophical debates, in which quick= ness of thought is shown easily altering opinion(9).

Gorgias expatiates on the subject of the various forms of the influence exerted by the lófos and its $\pi$ tili upon the soul: bat the conclusion is always the same, and it is clearly

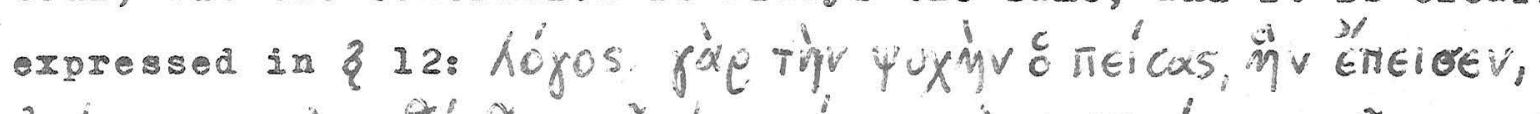

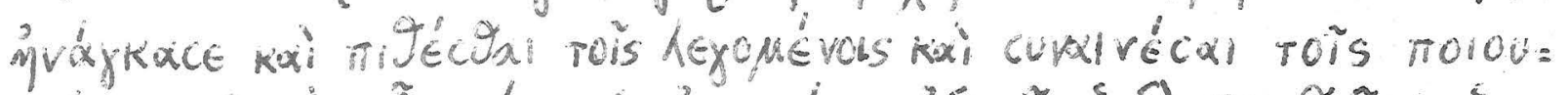

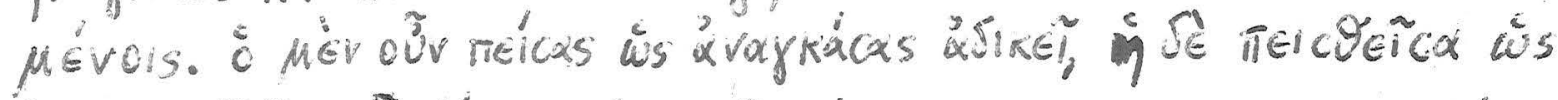

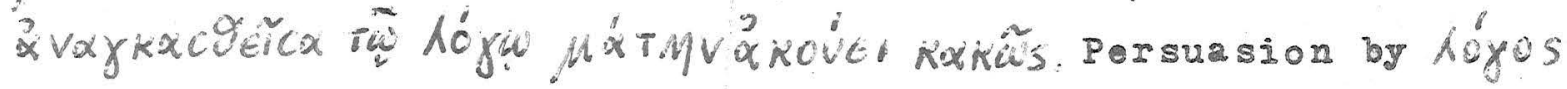
Is equivalent to abduction by force, as nobody can avold to "consent to mhat is done" if be "agrees to mbat is said", In other words, nobody can help acting in accordance with the considerations to which he has been brought. In socratic torns,

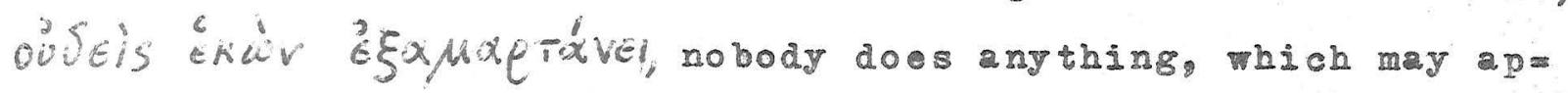
pear wong from a better point of ririr viow, without consi=

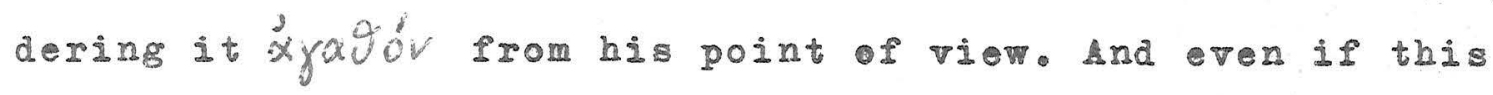
point of view is the visual perception of those objects which induce us to fall in love with them, the situation doos not chonge, as Gorgias says in the last section of bis spech: el

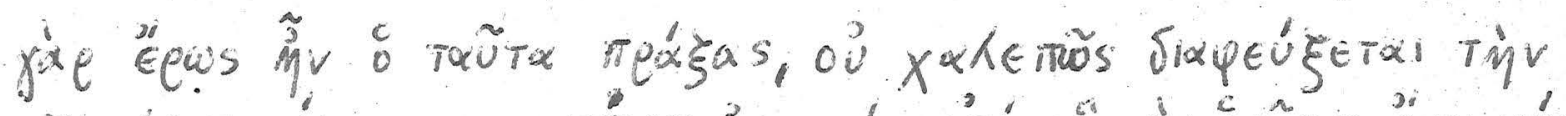

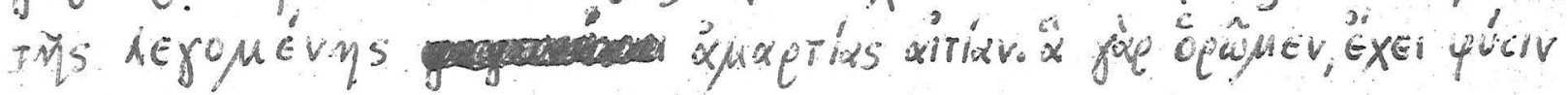




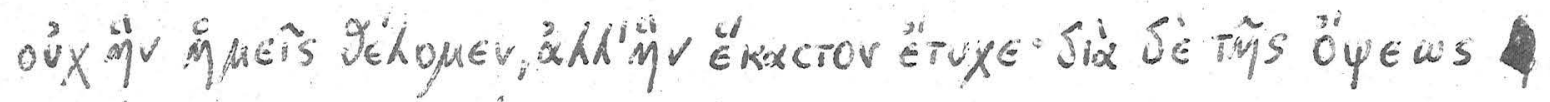
quxy kiv rois reónoss runoürai ( 915$)$. We see the things as they happen to be, not a we want them to be! And what fol m lows seems to anticipate some wellknown socratic analyses of the neture of fear and courage, as situations of the soul de pending from its way of seoing things as Jeir which we find in Plato's Protagoras and Laobes(10). Tho gene= ral conclusion is repeated in 2 19: is tros is a god, gods are

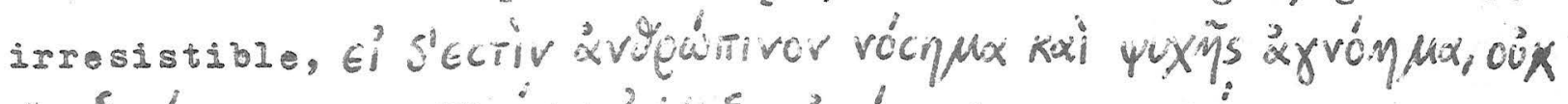

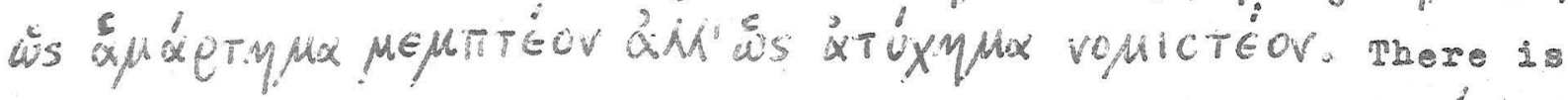
no neod to chang bere, with Weidner and Immsob, rophctét

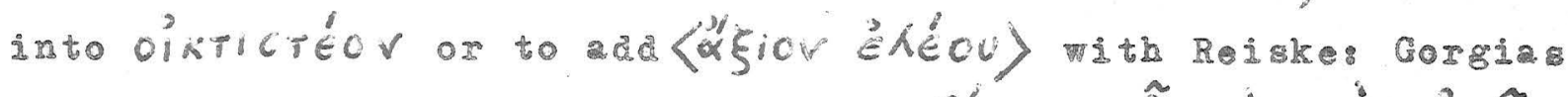

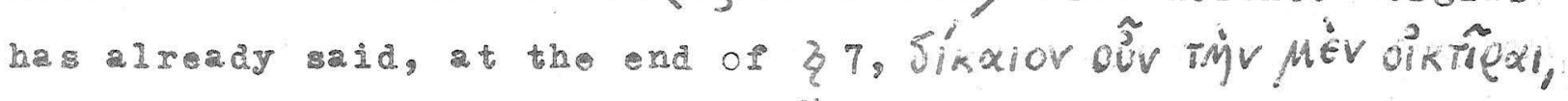
expressing the sam idea of the elfos of the "compasion" de=

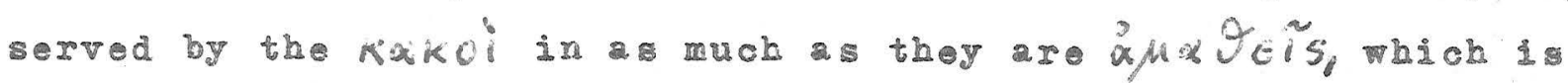
so common in all the platoni pasages concerned with the so cratio principle kxós ckiv oujeis(11).

Lot us now seo tho Palamedos. Tho ar horo defo himself by proving, first, that be could not bave earried into offect his suppesed treason even if be bad wanted to, and, secondy, that he could not have wantod to porform tho actions of which he is acoused, oven if ho had had the opportunity of performing themo The first part of the defence, which is by far the shortest of the I two, does not concern our problan (as the first part of the Helena did not). But the second part is a continuous reassertion of the principle which we know as the basis of so= cratos thics. Right from the boginning, in 313 Palamedos aks: - What motive could I have had? - And the reason given for this question is a statoment of that principlo: oujeis yie

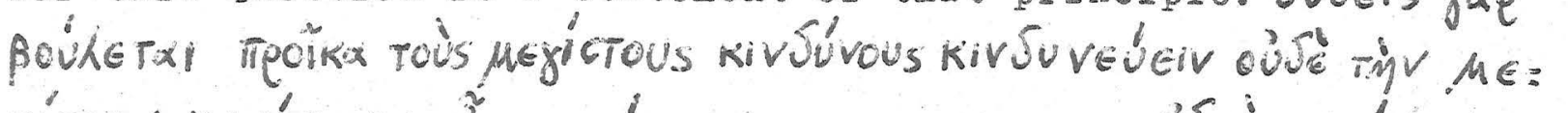

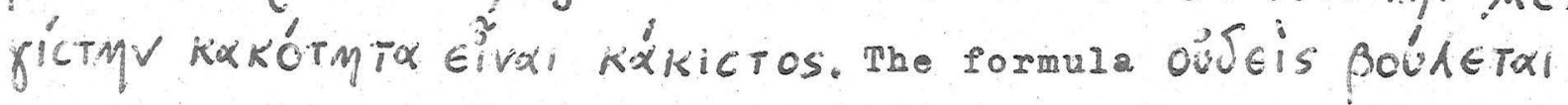


Tpoikx tival kikictos corresponds almost literally to tho

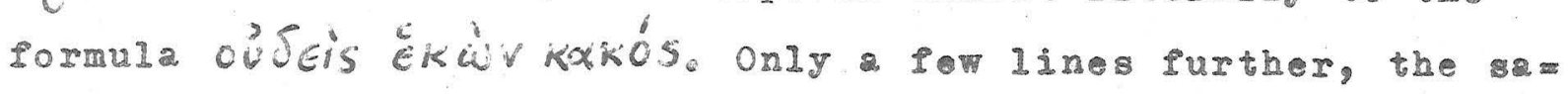
me presupposition is expressed in tho following passage:

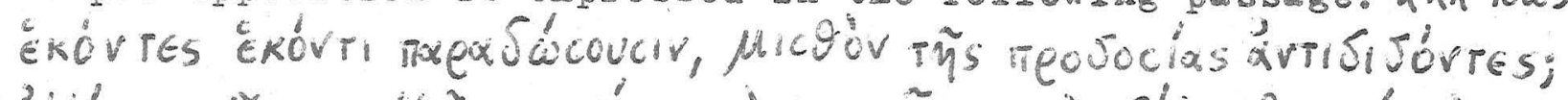

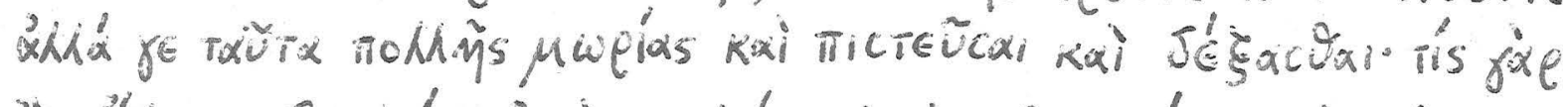

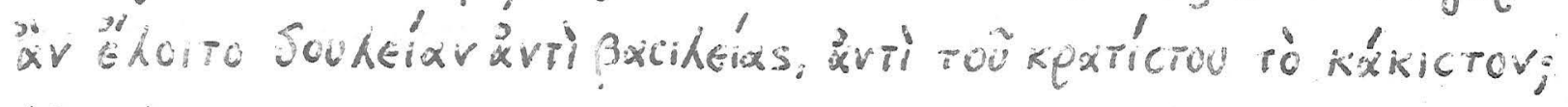
(3 14). As a matter of fact, the impossibility ol "choolsing the worst instead of the besti is a typical pointirequently underlined by Socrates in the demonstration of bis principle. At the beginning of 216 we read the sentence rai Minr ouj a

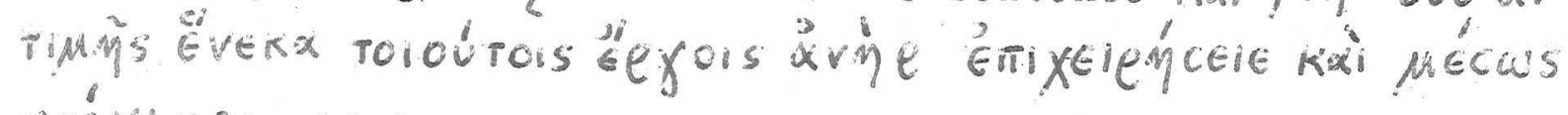
feovMOs; wich presupposes the idea that a reasonable man al cannot do thing which he judges baxnful to himsele. And 218

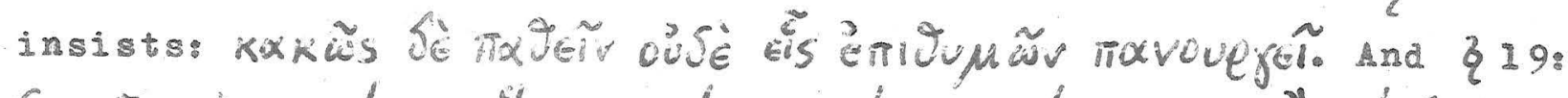

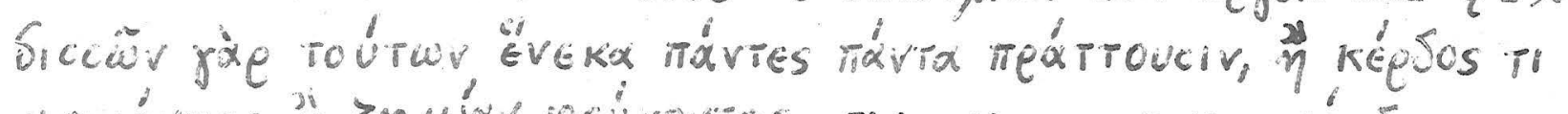

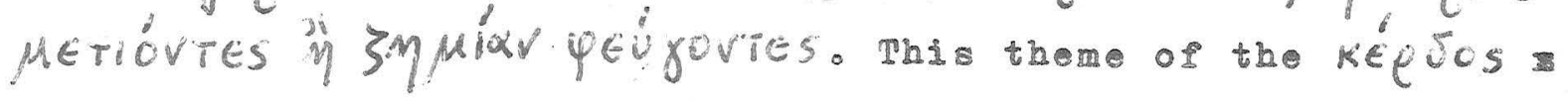

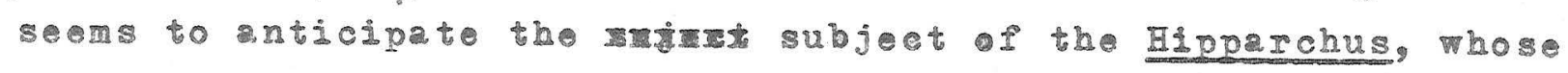
connection with the principle nemo sua sponte peceat I think to bave proved sufficienty(12). Finaly, in 25 Palamedes mays that bo cannot be acused at the same time of two opposia

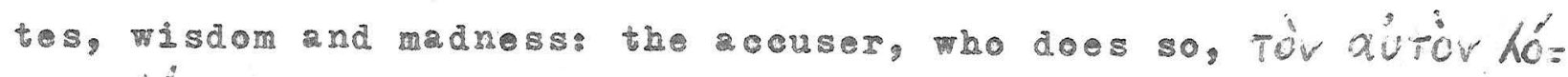

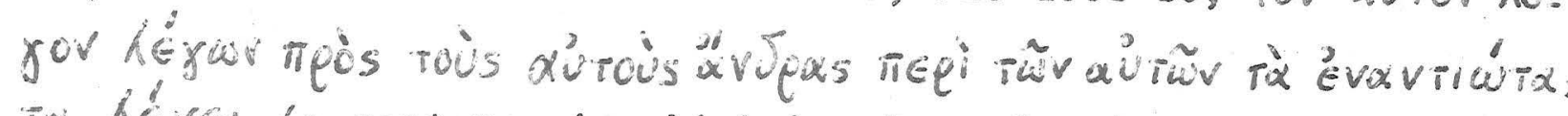
Tx hefel (a sontonce in whoh has been found an echo of the contemporary discusions abut the logical rule which should later be called the Law of contradiction). And here follows 326 to which wo shall compare a corresponding passage from Platois Apology of Socrates:

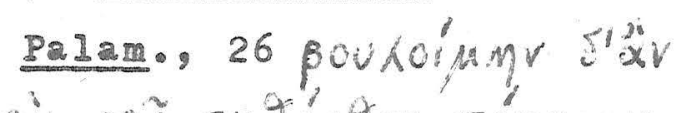

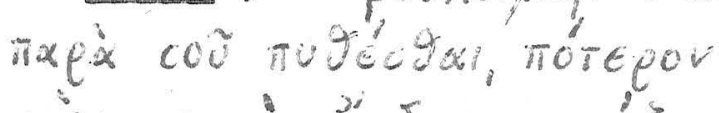
rous coyous avjeas ropíseis

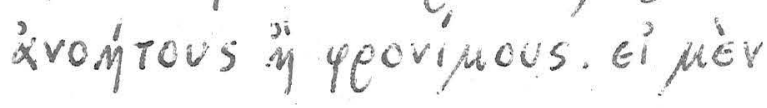

PI. Ap01.25D Ti SMra, $M G=$

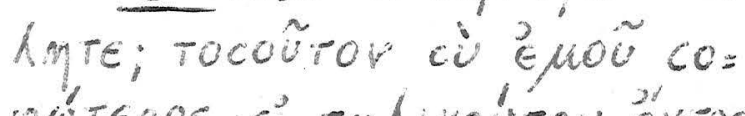

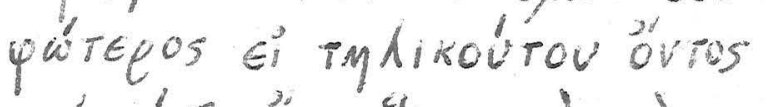
TMkiróse wr wete ci $\mu$ eV 


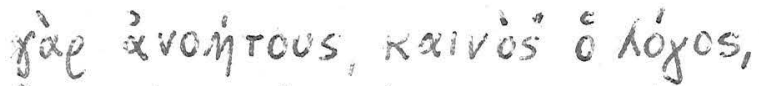

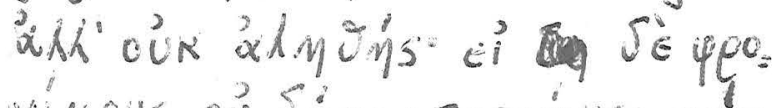
vikous, ob sinnou mpocinkel rous ge peovoúrtas ézapaptáreir. ins Mejictas apaptias kxi Mahor alpecial kaxis net na.

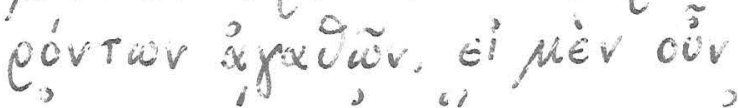
eipl copos, oix ípletor el Simpaptor ou coyos time ou.

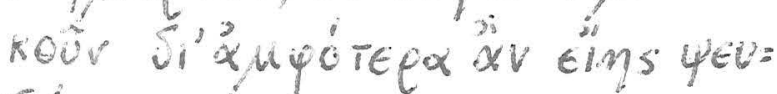
Sins.

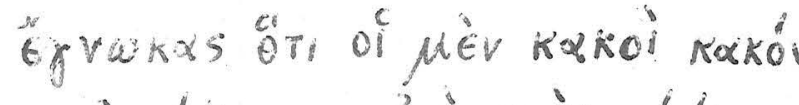

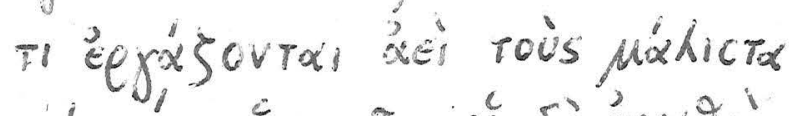

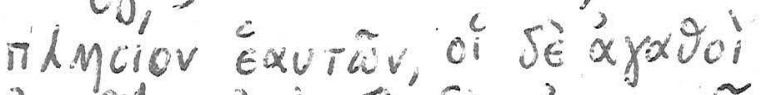
aragov, ejo ie un eis rocou.

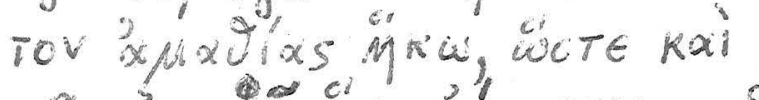

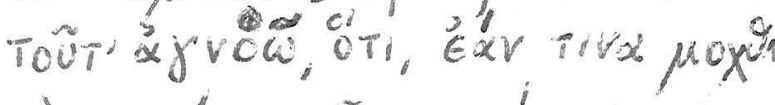
por Torigca teor curórtur, kiv. SUVEve nazoor il hapeir an'

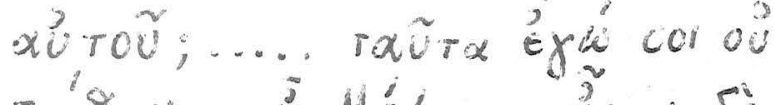

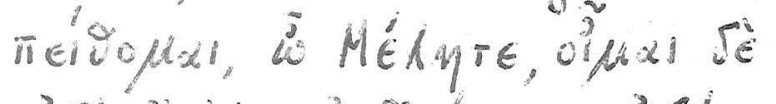

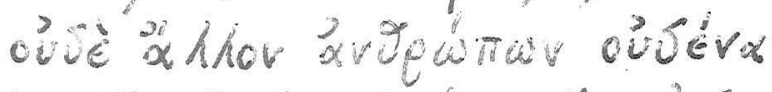

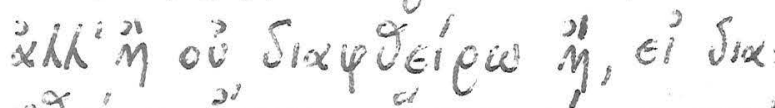
quelew, akuv wete u je rat

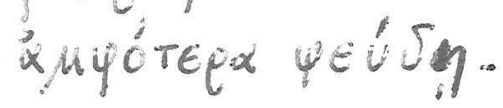

Gorgiast passage, even taken by itself, is completely so= cratic in its content: all its words might have been sald by Socrates in a platonie dialogue. But oven more astonishing than this coincidence of the main principle both of Helena and Palamedos defences witb tho main principlo of Socrates ethics is the similarity of this passage to the passage quoted above parallel to it. They end practically with the same sentence, apter two formulations of a dilemma which is also substantially the same, bocase it refors always to the principlo nemo sua sponte pocat, according to which nobody can, at the same tim

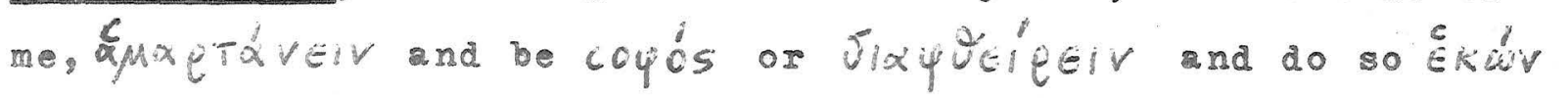
(13). Now, the coincidence between Gorgias" Apology of Pala medes and Plato's Apology of Socrates is not at all limited to this passage, but permeates the entire structure of both works. In In order not to take too mech space with quotations, we only mention, for each subject, the corresponding passage (indicating both works with tho initials of their authors 
and with $X$. Xenophon's Apology, when the corrispondence extends to it too)。

Death is not the real Issue: everybody is condemned to die: G. 2: P.38G-D; X.27.

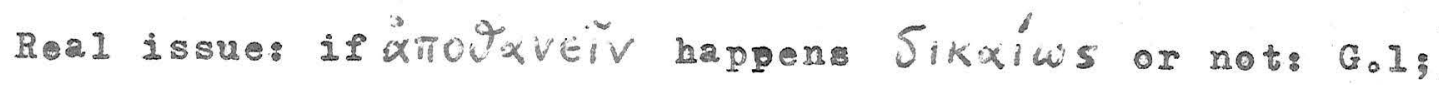
P. 34F-35C:

Death is preferable to ajcyeóv bebaviour or repute: G.35: P. $38 \mathrm{~g}-39 \mathrm{~B}$ 。

Judges who may condemn people to death should not decide in one dag: G.34-35: P.37A-B。

If you kill me, my fame will cause you to be blamed: G.36; P. 38 C.

I could not go elsowbre 2 s an exile: ry bosts would become susplcious, and it would bo aics oú Aibís (14), in Grece

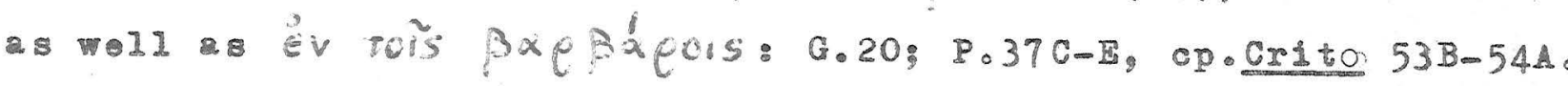

Not only I am not guilty, but I am pour suepfetys: G.30: P.36C (the bost proof of my innocence is aray mtire Iife: $G \cdot 28-29 ; \quad X \cdot 3)$.

I wil not use lamentations and prayers in order to move

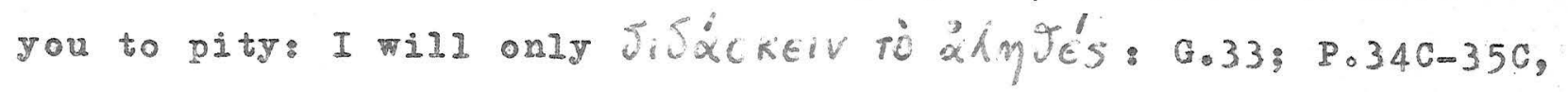
CD०38D-E: X。4:9.

Interruption of the atiohofeicial by a SixhÉfectxi witb the accuser: G.22: $\mathrm{P} .24 \mathrm{~B}$ If. $\mathrm{X}_{0} 19 \mathrm{Il}$

Now we can understand why in the enumeration of the most im portant sophists made by Socrates in Plato's Apologr (I9E) Gor= gias comes first, before Prodicus, and why the first hero, kil = led by an unjust sentence, whom Socrates thinks to meet im Ha des, Is Palamedes (4IB)! Not only must be rx bave beard Gorgias presuppose in bis discussions the same principle upon which be had to base bis etbics(15): he must also bave cleary semome red Gorglas" Apology of Palamedes, when bo pronunced before bis 


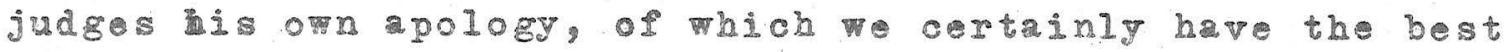
document in PIato' work. After all, this news is definitoly given to us by Xenophon, who presents Socrates himself as rem

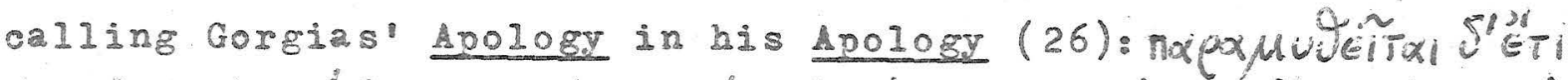

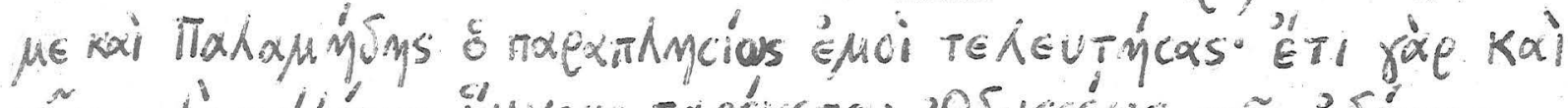

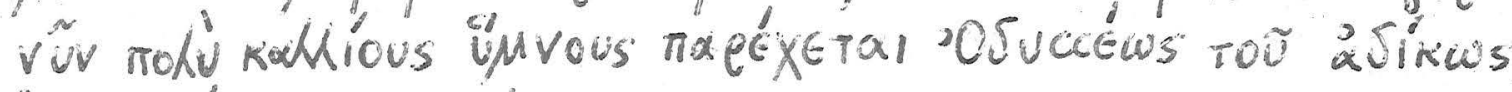
arokteivavtos auróv Josef Morr(16) has well argued that this passage cannot be an allusion to turipids: Palamedes (

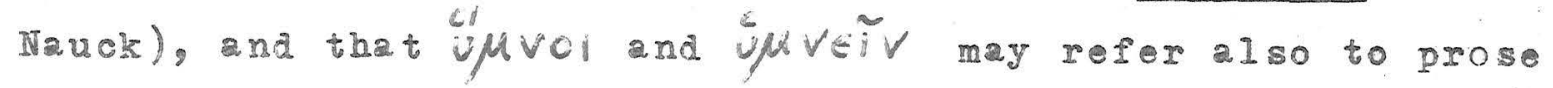
works: as a matter of fact, Gorgias himself (tro5b Diels-Kranz) seems to call üpvous his ancomia. Moreover, Morr (who bad III strongly underlined the coincidence betweon Gorgias Palaredes 2nd Xenophon's Apology of Socrates as to the point that every= body is already condemned by nature to die, without noting, bo= wewer, the far more numerous coincidences, in this and in other points, with the platonic Apology) quotes Xen。 Mem.IV, 2,33 Ta SC

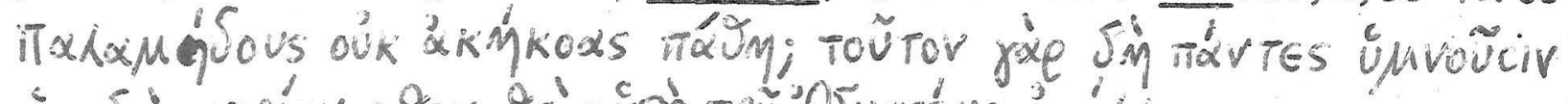

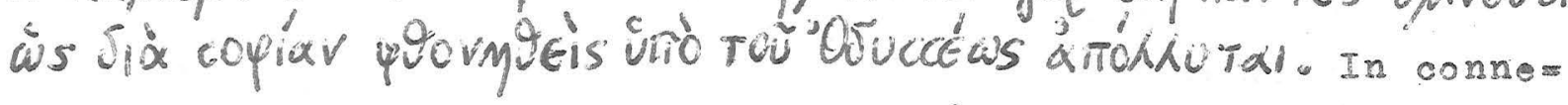
ction wib this interpretation, accoring to which ulysses bad accused Palamedes because ha was envious of his coyíx, Morr repers to Gorgias Palamedes 25 (copiak how kximpopeis), in order to show that the situation bere is the same, and that the= refore tbis is the work groted by Socrates in Xenophon.

This may be true or false, but in any case Xonpphon has been particulary influenced by Gorgias, and certain aspects of this influence may confixm what we have seenconcerning the relation between the sophist and Socrates. Nestle, who has carefully studied the sophistic heritage in Xenophon(17), recognises, for

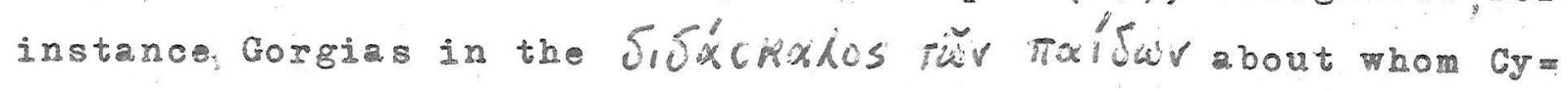
rus is told by his father in Inst.Cyri, I, 6,31. He ESíSxeker

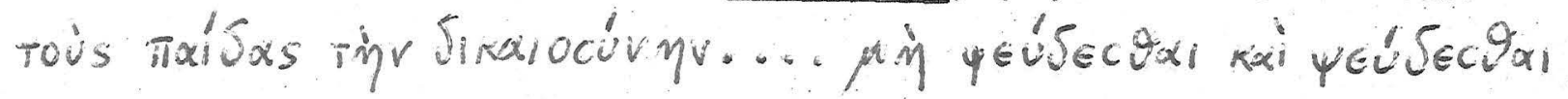




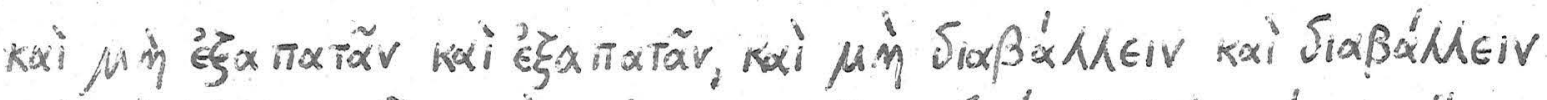

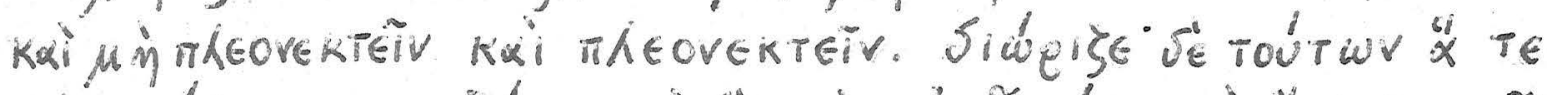

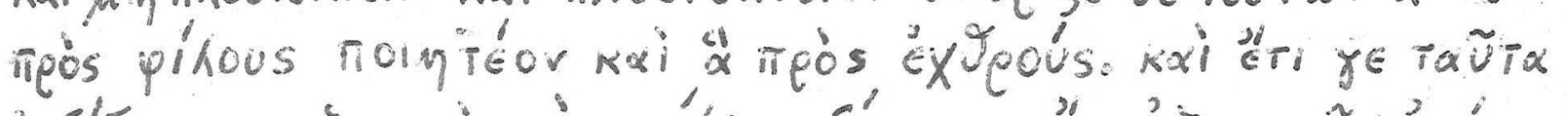

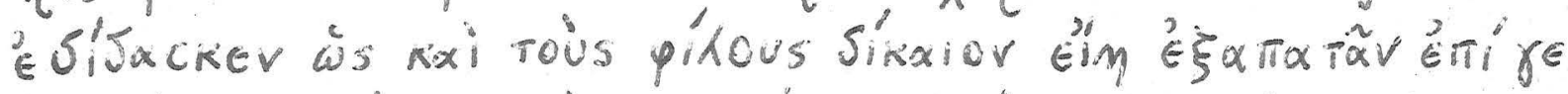

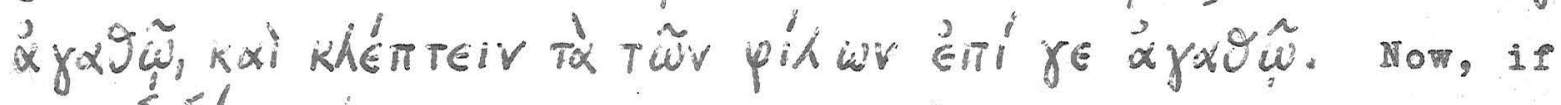
this Jijóckxhos is reariy Gorgias(18), it is also easy to see that his doctrines are vary similar to certain loci communes of the ethics of Socratos, who liked to show, in his oriticism of the traditional aperxi, how what is good from the point of view of a single aefị in certain cases is not good in otber cases, for examle that which is with reference to friends may not be good as regards enemies, and so on(19). On the other side, Nestle ar agreos with Hertlein and Ritter, who see a symbolic represontation of both the destiny and the fundamental moral principle of Socrates in the portrait of the man of whom Tigranes tells cyros that his rather sentenced him to death bo cause be thought that he was corrupting him, whereas the man

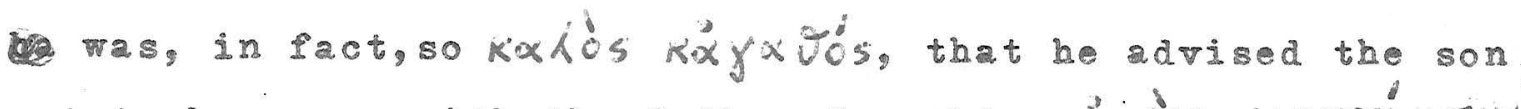
not to be angry with the father for this: ou yole kxicrolu tivi

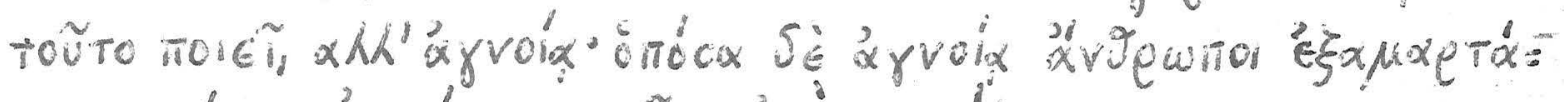

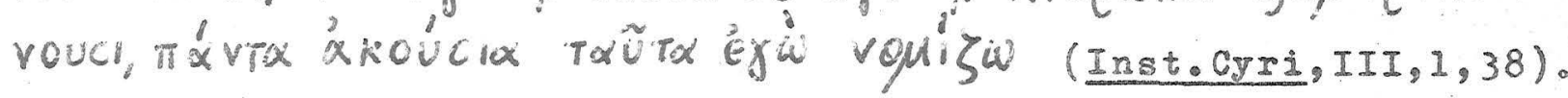
And so we see that in the main educational work of Xenophon, it is Socrates and Gorgias who seem to be present, as masters of the youth worthy to bo idealized together: Corgias maintaining points familar also to socrates, and Socrates reasserting his nemo sua sponte peccat.

Anyway, be it as it may with Kenopbon, the presence of the a fore-mentioned principle in Gorkias Helena and Palainedes is evident, we believe, after our analyses of their contents. G. Bux (20) was right in remarking the that the "logical" structure of both those discourses has nothing to do with the firios of 
Teisias and Corax. Botb defences do not presuppose any likely reconstruction of facts individually connected rit with the personal situation of Helenf or of Palamedes as for instance 211 other defences of Heles in Greak literature do, including that, paticulary ailly, of Isocrates(21). They axe based only on general arguments, which could be employed by any otber I porson accused of adultery or treason. But it is no use to say that this type of arguentation isa an apagogischer schlussbe= Weis, whose presence in both defences as well as in the TEpi Eb TOU AM OVTOS declares all of them to be onIy orercises or elean tio dialoctics(22). What is important, is the real contents or this Beweis: and this, we have seca, is nothing else than the sum of the considerations, upon which the nemo sua sponte pec= cat of Socrates is based.

The date of Corgias discourses is not certain, but no one has thought that they might have beon witten after $410 \mathrm{~B} .6$. (23). As it is also quite unlikely that they were composed by the vory old Gorgins after the deathor Socrates, there is no reason to change tho ancient viow, that the Defence of Palame= des influenced Socrates' own defence, as weIl as its description be PIato and Kenophon, and not Viee Versa. At the same time, the idea of the irresistible power of 10 or and nelfi, so brilliantly outlined in the Helena, coincided with the oudels Ekiv kxies of Socrates, but also confronted him with the most important problem of moxal conduct. In fact, Gorgias, envisaging the nemo sua sponte peccat in its most elementary form, might fall in a sort of moral indiffrence. Everybody could act only according to bis persuasions: so everybody could dominate the others if be was able to persuade them(24)! Against this new tyranny of the 10gos, wich was both throatoning the indipera

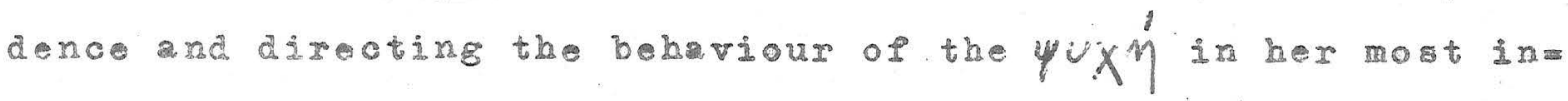


timate realm (by the way, even this ldea of the soul as the seat ol consciousness and poral conduct, in which Burnet and Taylor saw the most important lement of Socrates' philo= sophy, bas proved present in Gorgiast discourses), Socrates had to find a remedy. And this was not a rapudiation of the nemo sua sponte peccat, but the discipine of the fiell wi by the Jik kojos. Everybody acted according to bis private rea sons, but everybody had to So SOV Aoror of these ramons and to xiteir Áror of the reasors of the others, in order that the better ones could exerce their better Tei Fi: so the $\mu$ i :

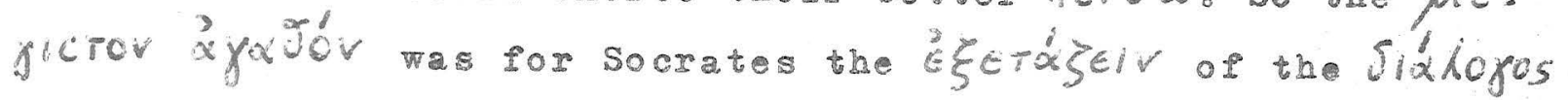
both in this life and in any other possible life(25), and the

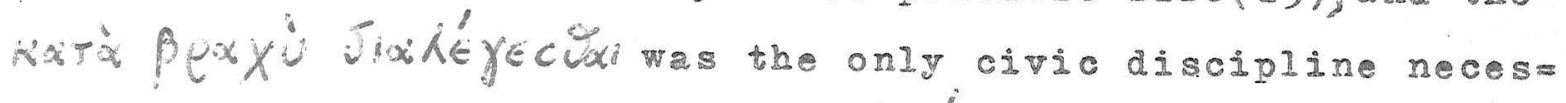
sary in order to check the faxkeoloyia of the rbetors and theix possible bad TEltíl (26). But this was not enough for Plato, who was not only a teachor but a politician as well, and did not possess the quiet socratic patience to wait for tbe slow $10=$ sults of the fixhoyos. The fact that wo find the manifesto of his new position in a dalogue entitled Gorgias is probably

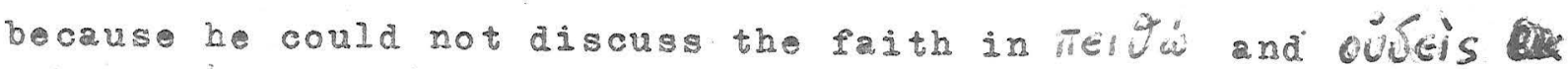
enkr ratios and Jikhoyos of bis mater socratas without beginnins

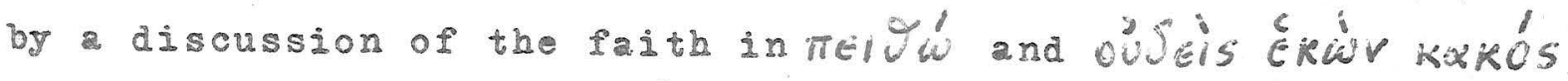
of the master of socrates bimsell。 


\section{Gotenotes}

(1) F.G. Welker, Prodikos ron Keos, Vorganger des Sokrates, in Rhein。 Mus. P. Philol., 1832 and 1836, reprinted with additions in Klei= ne Schriften, II (Bonn 1845), 393-54l. Socrates himself says, in PIato's Meno 96D, that Prodicus had been his teacher。 But eren if this is not a joke, to study under and to be a disciple of are not the sare thing.

(2) Stond Ranuls, Der eleatische Satz vor Widersoruch, Coporhagen, 1924: and gice prearistotelica, in Giornalo critico della pilosoria ita= 1iana, VIII, 1927, 409-22。

(3) See e.go the passages quoted in Diels-Krang, 84 4 13-18.

(4) May I refer for this to my article Socrate, in Nuova Antologia, Norember 1955, 291-308, and to Logo e Dialogo (Milan, 1950).

(5) Helena and Palamedes are still considered only as "orereises" by K. Froeman (The Pre-Socratic Philosophers" ${ }^{2}$, Oxford, 1949, p. 359) and as "jeux d'esprit" by B.Duprél (Les Sophistes, Neu= chatel, 1949, p.61), although be cis bas carefully analysed ma ny a spects of Gorgias ethies. As to the interpretation of Gor= gias by M.Untersteiner(I Sofisti, Turin, 1949, pp.114-248), I find it very difficult to understand, oven in the english tresis translation by KoFroeman (The Sophists, Oxford, 1954, pp.92-205)

(6) Lauatio Helenae, 14-150 That Isocrates' quotation of the yeuk:= yovid neet rís Eherps realy refers to Gorgias and not to another apologist of Helen, is How generally accepted.

(7) 2 2. The quotation is from the summary given by $\mathrm{K}$ 。 Freeman in hor Ancilla to the Pre-Socratic Philosophers ${ }^{2}$ (Oxford,1952), p.131.

(8) The feeling of the difficulty of his task is again expressed. by Gorgias some lines further, if the beginning of $69 \mathrm{has}$ to be

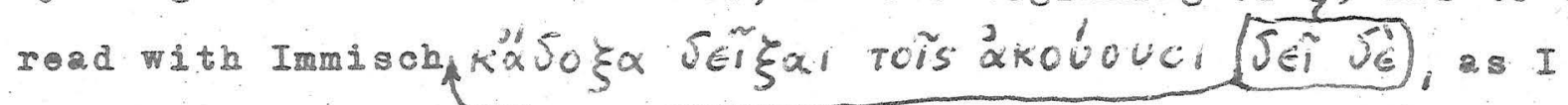


think it has (all other reaings give a poor sense).

(9) From the sumary of K. Freeman, which is bere almost a complete txans 12 tion.

(10) Compare for example what hore $3216-17$ say about the yópos as ongendered in the soul by the notion of a future danger with

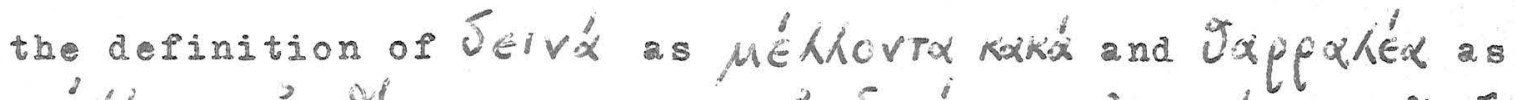

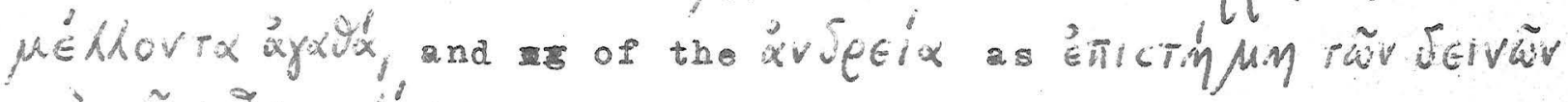

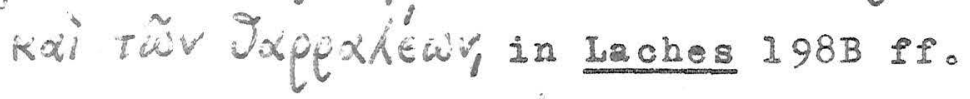

(11) This principle, which clearly ascribed to socrates also by to nophon and by Aristotle, was evidently considered so important by Plato that be never disomned it, through 211 his Iife, al= though he did not follow it in many developlfments of his phi= losophy. Cp. for instance Apol.25D-26A, Protag.345E, Hipp.Min. $376 \mathrm{~B}$, Hiop.Major 296C, Gorgias 488A, 509E, Reso.336E, 589C, Tim.86D-E, Leges 734B,860D.

By the way, as in Teej Sikpiou 374 A socrates quotes this principle as expressed by "a poet" who said oúfeis ektir novy=

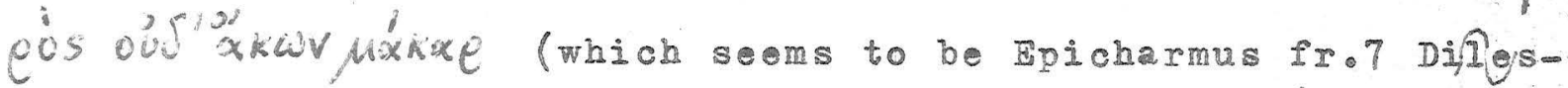
Krane with the two last words so changed from ar alv éfWV), and as in Protag. 345E bo ironically finds it expressed in Si= monides" poem, I wonder whetber that sort of play with ancient poets (which is referred to also in PIato's $4001.22 \mathrm{~B}$ ) may not bave beon extronded by Socrates also to Eomero In this case, oú

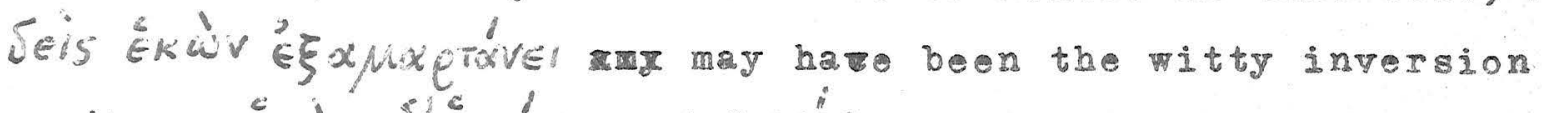

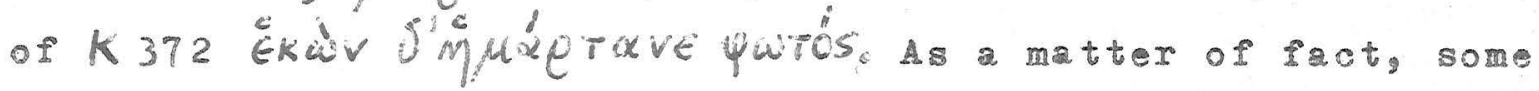
WSS (quoted by AIIen, ad 100.) say at this point that some people substituted the first bemistich with that of $\wedge 350$,

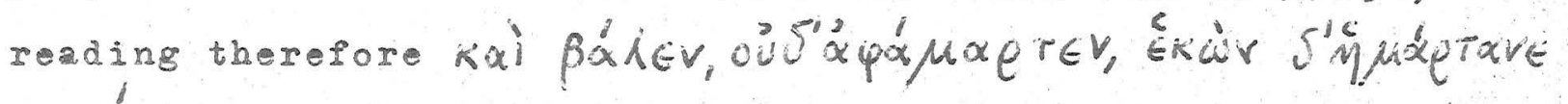
quros. They probably wanted to restore the barmony between

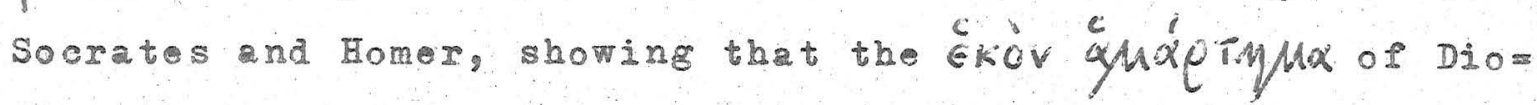


medes was not a real akjermpay otherwise it could not have $\operatorname{bentent}$

(12) Soe my commentary of the Hipparchas (Florence, 1938), where I bave also tried to show that there are many reasons to believe in its a utbenticity.

(13) It is 2 so to be remarked that, few lines before, socrates bad

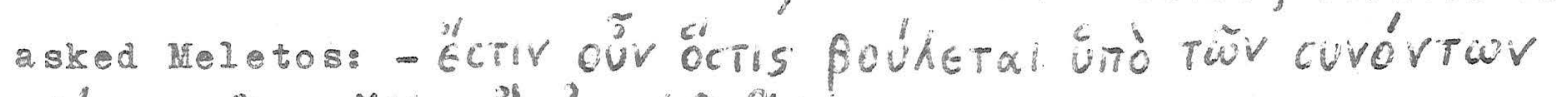

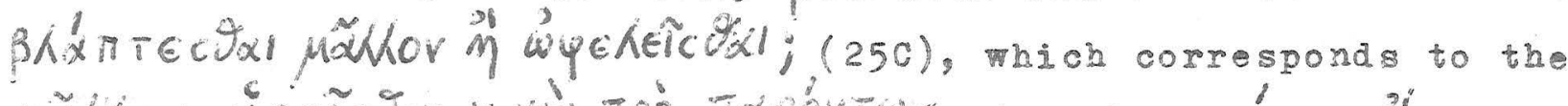

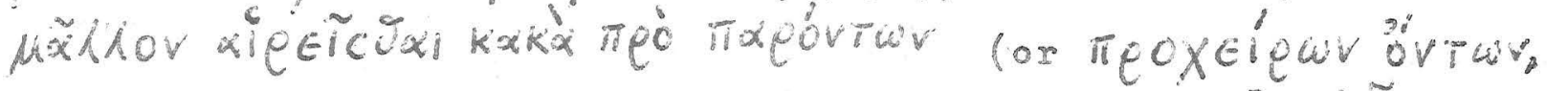
il one prefers Radermacher's to Diels' conjecture) Corgias passage whereas the term XMxpthMxty, corrosponding

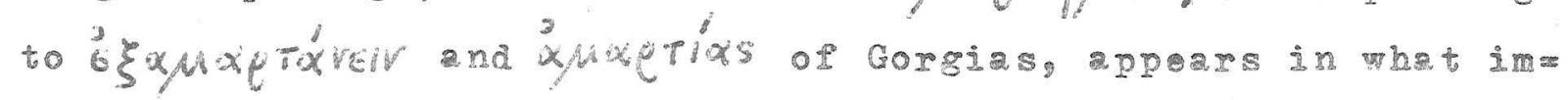
modiately follows in Plato's Apology (26A)。

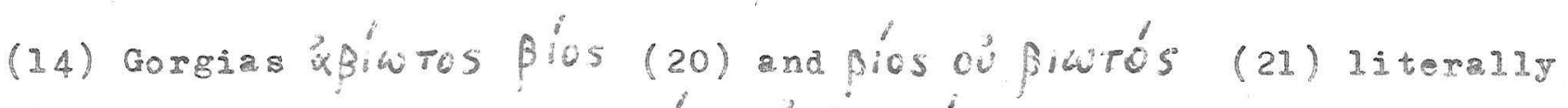
correspond to Platos fios ó Bicitis, which appers just a littio Iurther in bis Apology (38A). It is to be remaked that such expressions, acording to the "Wortindex" of Krang in Díls' Vorsokratiker are used only bere in all the presocratic period ( $x$; 3 cs in Antiphon bas just the opposite meaning). I cant therefore understand why Untersteiner, in his commentary of this passage (I Sofisti: testimonianze e frammenti, II, Flo=

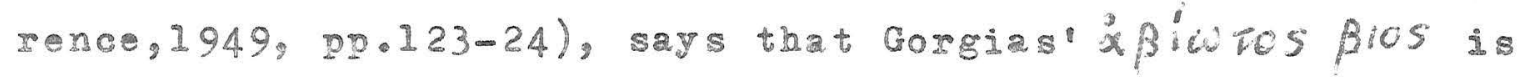
an "espressione empedoclea", quoting mpodocles Ir.2,3 as reac= ing zoms apícu mis is ondy conjecture of scaliger, the text givon by sextus is 20 mincl piove

(15) And possibly also discuss topics which became th the same time well-known points of departure for socratic discussions: for

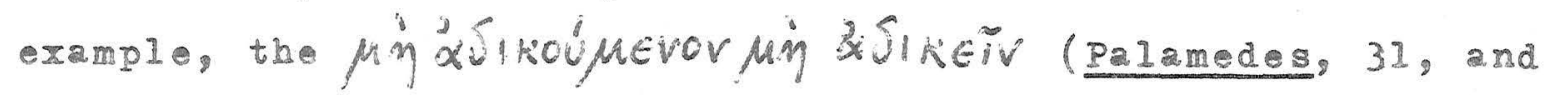
CD. Crito $49 \mathrm{~B}$ If.) or the idea that one has to help iriends and injure enemies (PaI, 18). 
(16) Des Gorgias Palamedos und Xenophons Apologie, in Hermes, IXI (1926), $467-70$.

(17) W. Nestle, Xenophon und die Sophistik, in Pbilologus, XCIV (193940). 31-50. On the inflence of Gorgias on Xenophon seo also HoSohacht, De Kenophontis studis rhotorieis, Berl.Diss. 1890, and $\mathrm{K}$. Mingcher, Philologus, 13 Suppl.Band, 1920, p.3.

(18) Nestle sees in Gorgias philosophy the common source of what is said in this passage, in $\Delta$ orobi Kóy0l, 3, and in Plato, Resp. $332 \mathrm{E}$ \&ீ。

(19) Any exiticism by Socrates of the single traditional âferax in the eary platonic dialogues might be quested as an example por this (e.s. the aiscussion of the curpocury in charmides: it is not equivalent to go alow and dignified, because in certain ca= ses it is more cwipeov to hurry, and so on).

(20) Gorgias und Parmenides, in Hermes, 1941, 393-407. Certain coin= cidences between Palamedes and PIato's Apology bas been also remaked by HoGomperz in his defence of the autbenticity of Gorgias' work (Sophistik und Rhetorik, Leipzig, 1912, 9-11)。

(21) The bistory of the defence of Helen bas been treated by M.S. Khafaga, Absolutio Eelenae, in Bulletin of the Faculty of Arts, CaIro, 1950, 85-98, which unfortunately I Was unable to trace. The fact that Gorgias discourses do not concern any individual circumstance of HeIen's and Palmedes" actions, but generalIy prove every adultery or treason to be either impossible or un= intentional, had been stressed also by H.Gomperz, Sophistik m und Rhetorik, II ff. But, considering such demonstrations simm ply as absurdities, he saw in them only the proof that Gorgiag discourses were mere jokes。

(22) Whrougb a similar reduction of the real arguments to their ex 
structural pattern E.Gomperz (Sophistik und Rhetorik, Leipris, 1912, 1-35) had already arrived to the conclusion that TGei rov Min ÓrTos was a pure joke not less than Helena and Palamedes. I think to have demonstrated, on the contrary, that a so the Tee rou $\mu$ in ovtos is neitber a joke nor an exercise, but a bighly ironjcal reductio ad absurdum of the eleatic philosophy (especially of zeno): see the chapter on Gorgias in my studi su11' BI.eatismo: Rome, 1932 .

(23) Helena is placed by Preuss (De guxip. Helo, leipzig, 1911) rar between the Troade and the Helen of Euripides, in 414 B.C., and by Pohlenz (Nacbrod.Gott.Ges.d.Wiss. 1920, p.166) before the Troades (see also K. Freeman, The Pre-Socratic Philosophers, p.363). The Palamedes is dated before $4 \mathrm{~m} 411$ by Maas (in Hermes, XXII, 1887, 579).

(24) In PIato' Gorgias 452D-E Socrates asks Gorgias what be thinks

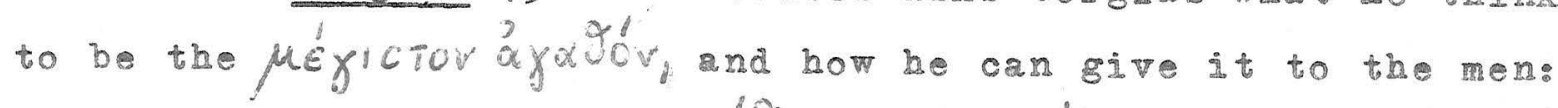
he ansers that it is the Telfeir rois kófors, because this

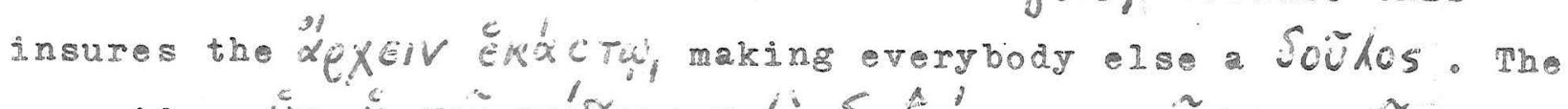

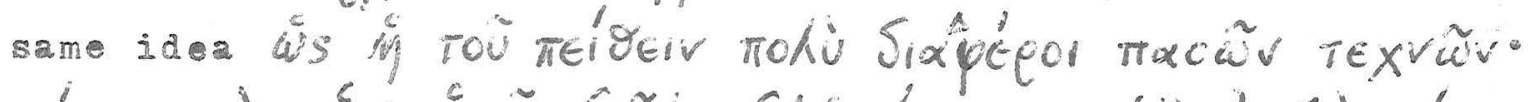

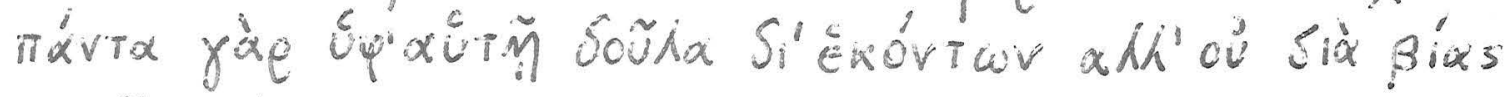
7rol0170 - is attributed to Gorgias in Phileb.58A-B. So the nel $U_{i}$, which was the essential instrument of any democratic opposition to the tyrannical Bix, becomes the instrument or a new sort of tyranny ( $\beta i \alpha S_{1}$ EKóvTWV), until it is cbecked by S12NO805.

(25) Plato, Apol. 38A, 41B; and cp., for the interpretation of these passages, my article Socrate quoted abore, note 4.

(26) This explains also the fundamental value of the opposition Ir

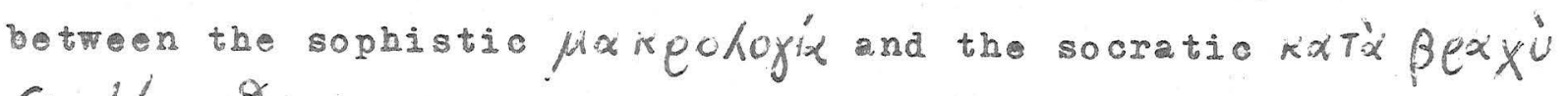
Slakéfecual in Plato's Protagoras. According to Dupréel (So 
phistes, 80-81) Plato, Gorgias 449B-C might be considered as a

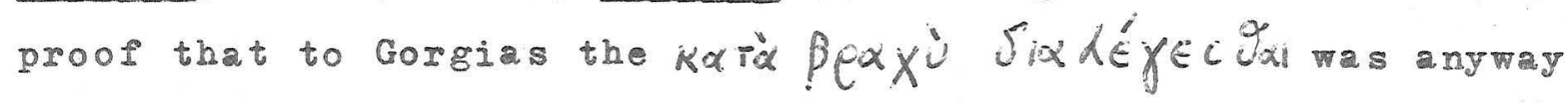
less alien than to Protagoras. Mhis would be another sign of bis particular proximity to socrates. In any case, the only one who had not understood anything at all was poor Prodicus:

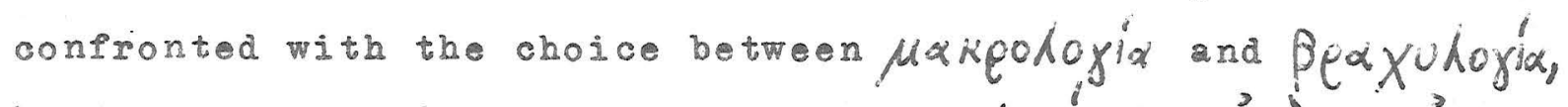
he just recommended a moderate lenght! ( 10 VOS aŨOS EUंpM=

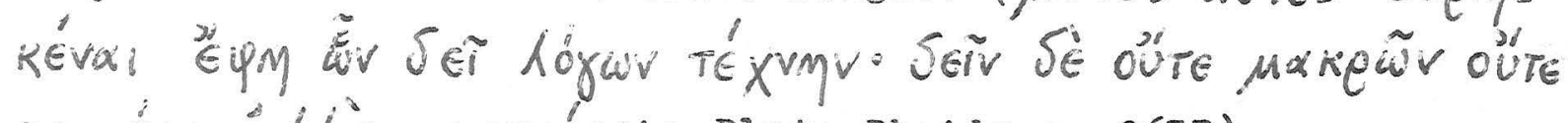
pexxew a 